\title{
Kannattaako asiakkaan toimijuuden ja itseohjautuvuuden vahvistaminen?
}

\author{
MARI PUNNA, KAISA MALINEN, EIJA SEVÓN JA SANNA SIHVONEN
}

Nykyisen hallitusohjelman sekä sosiaali- ja terveysministeriön parhaillaan käynnissä olevat kärkihankkeet (1) ja sote-uudistus (2) lisäävät asiakkaiden valinnanvapautta ja samalla tarvetta ottaa vastuuta omasta hyvinvoinnistaan. Ohjelmissa myös korostuu suuntaus uudistaa palveluita asiakkaiden omaa toimijuutta vahvistaviksi. Vilkkaana käyvän palveluiden järjestämistä koskevan keskustelun lisäksi onkin välttämätöntä tarkastella myös sitä, mitä uudenlaiset sote-palvelut edellyttävät niin asiakkailta kuin ammattilaisilta.

Uusien sote-palveluiden kehittämisessä on tärkeää pohtia ammattilaisten mahdollisuuksia vahvistaa asiakkaan itseohjautuvuutta ja toimijuutta. Erityisesti, ja edelleen, tarvitaan vahvempaa asiakkaan ja ammattilaisen tasavertaisten roolien esille tuomista toistensa yhteistyökumppaneina. Tässä puheenvuorossa tarkastelemme sekä toimijuuteen että itseohjautuvuuteen liittyviä näkökulmia Jyväskylän ammattikorkeakoulun, ja Jyväskylän yliopiston toteuttaman sekä Euroopan Sosiaalirahaston rahoittaman Minä ensin! Mobiiliteknologia sote-ammattilaisen työhyvinvoinnin ja asiakkaan itseohjautuvuuden tukemisessa -hankkeen kokemusten pohjalta (3).

\section{ASIAKKAAN JA AMMATTILAISEN MUUTTUVAT ROOLIT}

Itseohjautuvuus voidaan nähdä taitona ja pystyvyytenä hyödyntää henkilökohtaisesti sopivia välineitä ja keinoja oman hyvinvoinnin edistämisessä. Yksilö voi toimia itseohjautuvasti $\mathrm{mm}$. asettaessaan tavoitteita oman hyvinvointinsa edistämiseksi, suunnitellessaan omaa toimintaansa, sekä tunnistaessaan haasteita ja esteitä matkalla kohti asetettuja tavoitteita (4).

Pohjimmiltaan asiakkaan itseohjautuvuuden tukemisessa on kyse toimijuuden vahvistamisesta. Eri tieteenaloja yhdistävänä käsitteenä toimijuus määrittyy motivaationa, tahtona, selviytymiskykyisyytenä, pyrkimyksenä intentionaaliseen toimintaan, valitsemisena, aloitteellisuutena, osallisuutena, oppimisena tai hallinnan tunteena (esim. 5, 6). Toimijuus kytkeytyy ajatukseen ihmisten autonomisuudesta, toisin sanoen ajatukseen henkilökohtaisen hallinnan saavuttamisesta vuorovaikutuksessa ympäristöön, ja tunteeseen, että oma käyttäytyminen on vapaasti valittua ja vapaaehtoista sen sijaan, että se olisi toisten ihmisten tai sosiaalisten normien määrittelemää (7). Toimijuus liitetään myös kykyyn vastustaa omaan autonomisuuteen kohdistuvia uhkia. Hitlin ja Elder (6) puhuvat erikseen käytännön ja elämänkulkutoimijuudesta. Käytännön toimijuus on kykyä toimia toisin ja luovalla tavalla arjen päivittäisissä tilanteissa, kun taas elämänkulkutoimijuus viittaa kykyyn tehdä omaa elämää koskevia valintoja ja päätöksiä elämänkulun eri siirtymissä ja käännekohdissa. Kumpaakin toimijuuden lajia tarvitaan, kun omaa tai perheen elämää halutaan muuttaa ja ottaa käyttöön uusia toimintatapoja - liittyivät nämä sitten omaan hyvinvointiin, arjen hallintaan, työhön tai vanhemmuuteen.

Ammattilaisen näkökulmasta asiakkaan toimijuuden ja itseohjautuvuuden edellytyksenä korostuu kyky vastavuoroiseen, asiakkaan toimijuuden ja osallisuuden huomioivaan työotteeseen (8). Tässä yhteydessä on tärkeää, että toimijuus huomioidaan relationaalisena ja jatkuvana prosessina, jota rakennetaan ja neuvotellaan arjessa ja vuorovaikutuksessa ammattilaisen ja asiakkaan kesken (5). Toimijuuden käsite laajenee näin sisältämään kyvyn toimia yhdessä, jolloin se viittaa vastavuoroisuuteen, jaettuun vastuuseen ja yhteisölliseen oppimiseen (8). Yhteistyön lähtökohdaksi tulee näin ammattilaisen kyky 
kuulla asiakkaan tarpeita ja aloitteita, vahvistaa asiakkaan orastavaa motivaatiota, tukea ja kannustaa häntä valinnoissaan ja päätöksissään hyvinvoinnin edistämiseksi (ks. 9). Oleellista on kohtaamiseen, vuorovaikutukseen ja motivointiin liittyvä osaaminen ja rohkeus kokeilla uusia toimintatapoja (9).

\section{LÄHTÖKOHTANA ASIAKKAAN MOTIVAATION TUKEMINEN}

Kuten toimijuuden käsite tuo näkyväksi, asiakkaan itseohjautuvuuden tukemisessa on avainasemassa sen tunnistaminen mikä motivoi yksilöä oman hyvinvointinsa vahvistamisessa ja ylläpitämisessä. Yksilön toiminta on pitkäkestoista ja tuloksellista silloin kun se rakentuu sisäiselle motivaatiolle, eli kun tekeminen itsessään on palkitsevaa eikä sitä tehdä palkintojen tai rangaistusten vuoksi $(7,10)$. Kuten itsemääräämisteoria olettaa ja laaja tutkimusnäyttö osoittaa, ihmisillä on sisäsyntyinen tarve kokea kyvykkyyttä, autonomiaa ja kuuluvuutta (ks. esim. 7). Vaikka yksilölliset painotukset näiden tarpeiden välillä voivat vaihdella, ihmiset yleisesti kokevat palkitsevaksi toiminnan, joka herättää kokemuksia siitä että "minä osaan”, "minä vaikutan” ja "minä kuulun".

Vaikka motivaatio on yksilöllinen kokemus, on ympäristöllä ja muilla ihmisillä merkittävä rooli motivaation rakentumisessa (7). Motivaation näkökulmasta ammattilaisen rooliksi muodostuu asiakkaan kyvykkyyttä, autonomiaa ja kuuluvuutta tukevan ympäristön mahdollistaminen (10). Esimerkiksi sopivien haasteiden tarjoaminen, onnistumisen kokemusten mahdollistaminen, asiakkaan kykyjen tunnistaminen ja kehittävän palautteen antaminen tarjoavat asiakkaalle mahdollisuuden rakentaa kuvaa itsestään kykenevänä. Asiakkaan autonomian kunnioittamisessa keskeistä on omaksua asiakaslähtöinen työskentelyote, jossa asiakkaalla itsellään on päätösvalta ja vastuu itseään koskevista asioista. Yhteenkuuluvuuden kokemusta voidaan vahvistaa esimerkiksi vertaistuella ja hyväksyvällä ja turvallisella suhteella asiakkaan ja ammattilaisen välillä. Vastakkaisesti, asiakkaan motivaatiota heikentäväksi työmenetelmiksi on tutkimuksissa todettu esimerkiksi ulkoisten palkintojen käyttö, tiukat aikarajat, epärealistiset tavoitteet, tiukat määräykset ja kontrolli sekä painetta tuovat arvioinnit. Pitkäkestoiseen hyvinvoinnin edistämiseen riittää harvoin se, että yksilö tekee pelkästään asioita, jotka ovat hänelle itsessään palkitsevia. Tarvitaan myös ulkoisesta motivaatiosta lähtevää toimintaa. Tällöinkin ammattilainen voi tukea asiakkaan motivaatiota vahvistamalla mahdollisuuksien mukaan kyvykkyyden, autonomian ja kuuluvuuden kokemuksia.

Asiakkaan itseohjautuvuuden tukemista on kuvattu myös omahoitovalmennuksena (11) ja terveysvalmennuksena (12). Molemmissa lähtökohtana on yksilön autonomia, riittävät tiedot ja taidot oman terveyden hoidosta sekä yksilön motivaation, voimavarojen ja pystyvyyden tunteen vahvistaminen. Asiakas on oman tilanteensa asiantuntija ja ammattilainen tukee häntä prosessissa tarpeiden mukaan, minkä myötä asiakkaan ongelmanratkaisu- ja päätöksentekotaidot kehittyvät. Itseohjautuvuuden tukemisen ja valmentavan lähestymistavan erona perinteiseen potilasohjaukseen on se, että ammattihenkilö ei ole asiantuntemuksen yksistään omaava opettaja ja tiedonantaja, vaan asiakkaan omakohtaisten oppimiskokemusten tukija ja mahdollistaja (11). Keskeistä on asiakkaan ohjaaminen oman toiminnan seurantaan ja hänen tukemisensa toiminnallisten, konkreettisten tavoitteiden sekä arkeen ja elämäntilanteeseen sopivien tekojen toteuttamisessa (13). Terveysvalmennuksesta asiakastyön menetelmänä on saatu positiivisia tuloksia ja valmennuksen on nähty sopivan ammattilaisen työmenetelmäksi $(12,14)$. Sote-alan ammattilaiset ovat kuitenkin pitäneet osaamistaan riittämättömänä asiakkaan ohjauksessa ja kokevat tarvetta asiantuntijuuden kehittämiseen hyvinvoinnin tukemisessa $(15,16)$.

\section{AVAIMIA TOIMIJUUDEN JA ITSEOHJAUTUVUUDEN VAHVISTAMISEEN ASIAKASTYÖSSÄ}

Asiakkaan yksilöllisen motivaation ja hyvinvointivalintojen taustalla olevien tekijöiden erottaminen voi olla haastavaa. Niiden hahmottaminen on kuitenkin avain elämäntapamuutosten toteutumisen keskeisille tekijöille, eli toimijuudelle ja itseohjautuvuuden vahvistumiselle. Asiakkaan hyvinvointia edistävän ja sitä heikentävän käyttäytymisen näkyväksi tekemisessä voidaan käyttää mm. COM-B-mallia (17), joka ohjaa havainnoimaan asiakkaan motivaation (Motivation) ohella myös muita keskeisiä tekijöitä hyvinvointikäyttäytymisen taustalla. Malli soveltuu myös asiakkaan ja ammattilaisen yhteiseksi työvälineeksi. Se suuntaa tarkastelemaan yksilön tieto- 
ja ja taitoja (Capability), kuten esimerkiksi tieto kasvisten ja marjojen terveysvaikutuksista sekä taito hyödyntää niitä arkiaterioilla. Lisäksi malli auttaa tunnistamaan ympäristöolosuhteita ja niiden tarjoamia mahdollisuuksia (Opportunities), esim. taloudelliset resurssit ostaa säännöllisesti kasviksia tai lähellä olevat erilaiset ulkoilu- ja liikuntamahdollisuudet. Yksilön hyvinvointikäyttäytyminen (Behavior) on mallin mukaan edellä kuvattuihin käyttäytymisen osa-alueisiin pohjautuvaa toimintaa, jolloin asiakkaan muutoksen tukemisessa tulisikin keskittyä kaikkiin kolmeen osa-alueeseen. COM-B -malli tuo näkyväksi sen, että yksistään motivaation tukeminen tai tiedon antaminen eivät vie tapamuutosta kohti, jos asiakkaan taidoissa on puutteita tai elinympäristö ei mahdollista muutosta.

Asiakkaan tilanteen jäsentämisen ohella on hyvä pohtia, mitkä ovat yksilöllisiin tarpeisiin vastaavia ohjauksellisia keinoja. Ammattilaisten ja sote-palveluita johtavien asiantuntijoiden on hyvä tarkastella, mitkä käytettävissä olevat ohjauksen keinot ovat eri tilanteissa perusteltuja ja auttavat asiakkaita ratkaisemaan omaan hyvinvointiinsa liittyviä haasteita. Esimerkiksi sosiaalista tai vertaistukea kaipaavalle asiakkaalle tiedon lisäämiseen keskittyvällä ohjauksella ei usein päästä vaikuttamaan elämäntapamuutoksessa onnistumiseen. Keinoissa on kuitenkin valikoimaa, mm. kokemusten jakamisesta kannustepalkintojen pohtimiseen tai motivaation herättelystä ja vahvistamisesta oman toiminnan havainnointiin. Jo pienelläkin panostuksella ohjauksen suunnitteluun ja toteutukseen voidaan löytää kustannustehokkaita ja vaikuttavia asiakkaiden yksilöllisiin tarpeisiin vastaavia ohjauksen keinoja.

Osa ohjauksen keinoista voi soveltua hyvin kasvokkain tapahtuvaan ohjaukseen, kun toiset voivat toimia paremmin esim. digitaalisilla menetelmillä. Esimerkiksi aikaisemmissa tutkimuksissa elämäntapamuutoksissa vaikuttavaksi keinoksi todettu oman toiminnan havainnointi (18) voi sujua asiakkaalta joustavammin ja luotettavammin toisinaan esim. mobiiliviesteihin vastaamalla kuin vaikkapa sairaanhoitajan vastaanotolla edellisten viikkojen arkitapahtumia muistellen. Tarvitaankin uudenlaisia, myös digitaalisia, välineitä ja menetelmiä asiakkaan itseohjautuvan hyvinvoinnin edistämiseen sekä uudenlaista asiakaslähtöistä orientaatiota näiden palveluiden toteuttamiseen.

\section{HAASTEENA ASIAKKAAN TOIMIJUUDEN VAHVISTAMINEN}

Asiakkaan itseohjautuvuus ja toimijuus näyttäytyvät siis keskeisinä elementteinä yksilön hyvinvointia edistävässä käyttäytymisessä. Substanssiasiantuntijuuksien kehittämisen lisäksi sosiaalija terveyspalveluissa on tärkeää ylläpitää ja vahvistaa asiakkaan itseohjautuvuutta tukevia työtapoja. Ne huomioivat asiakkaan elämäntilanteen ja arkielämän, antavat kannustavaa palautetta toiminnasta sekä lisäävät hänen vastuunottoa omasta hyvinvoinnistaan. Sosiaali- ja terveysalalla tarvitaan vahvempaa toimintakulttuuria, jossa asiakas itse päättää omista tavoitteista ja toiminnasta ammattilaisen tukiessa asiakkaan voimavaroja ja toimintaan sitoutumista. On tärkeää huomioida, että asiakkaan toimijuuden korostaminen ei kuitenkaan tarkoita hänen jättämistä yksin hoitamaan omaa asiaansa, tai koske tiettyjä kriittisiä tilanteita. Sote-ammattilaisen rooli on merkittävä, sillä se voi parhaimmillaan substanssiasiantuntijuuden lisäksi olla avaintekijä asiakkaan onnistuneessa hyvinvointikäyttäytymisessä.

Minä ensin! -hankkeessa on kehitetty yhdessä sote-alan ammattilaisten kanssa uudenlaisia, digitaalisten työmenetelmien kehittämistä tukevia mobiilipohjaisia menetelmiä. Mobiiliviestejä hyödyntävän eKoutsi-mobiilimenetelmän avulla on luotu asiakkaan toimijuutta ja itseohjautuvuutta tukevia digitaalisia työvälineitä $\mathrm{mm}$. kouluterveydenhuoltoon, lapsiperheiden elämäntapaohjaukseen ja parisuhdeneuvontaan. Hankkeen aikana on myös kartoitettu valmiita hyvinvoinnin mobiilisovelluksia asiakkaan toimijuuden tukemisessa sekä kokeiltu niiden käyttöä osana asiakastyötä. Sote-ammattilaiset ovat olleet aktiivisesti hankkeen alusta asti mukana suunnittelemassa uusia työmenetelmiä. Tuloksista ja havainnoista tullaan kertomaan tarkemmin hankkeen päättyessä alkuvuonna 2018. Tässä vaiheessa voidaan jo todeta, että ammattilaisten tärkeä rooli työtapojen kehittämisessä on noussut vahvasti esiin. On ensiarvoisen tärkeää, että ammattilaiset pääsevät yhdessä pohtimaan nykyisiä työtapoja, ideoimaan ja esittämään kehittämisehdotuksia sekä kokeilevat uudenlaisia työmenetelmiä. Näin he vaikuttavat myös itse aktiivisina toimijoina työyhteisöjensä toimintaan luoden ja kehittäen uusia yhteisiä työkäytäntöjä. 


\section{LÄHTEET}

(1) Sosiaali- ja terveysministeriö. STM ja hallituksen kärkihankkeet. Luettu 31.3.2017. http://stm.fi/karkihankkeet

(2) Sote- ja maakuntauudistus. Sote-uudistuksen tavoitteet. Luettu 31.2017. http://alueuudistus. fi/soteuudistus/tavoitteet

(3) Jyväskylän ammattikorkeakoulu. Minä Ensin! -hankkeen tausta ja tavoitteet. Luettu 31.3.2017. http://blogit.jamk.fi/minaensin/

(4) Richardson J, Loyoloa-Sanchez A, Sinclair S, Harris J, Letts L, MacIntyre NJ, Wilkins S, Burgos-Martinez G, Wishart L, McBay C, Martin Ginis K. Self-management interventions for chronic disease: a systematic scoping review. Clin rehabil 2014;28:1067-1077. https://doi.org/10.1177/0269215514532478

(5) Eteläpelto A, Vähäsantanen K, Hökkä P, Paloniemi S. What is agency Conceptualizing professional agency at work. Educ Res Rev 2013;10:45-65. https://doi.org/10.1016/j.edurev.2013.05.001

(6) Hitlin S, Elder G H. Time, self and the curiously abstract concept of agency. Sociological Theory 2007;25:170-191.

https://doi.org/10.1111/j.14679558.2007.00303.x

(7) Deci E L , Ryan M R. The "what" and "why" of goal pursuits: Human needs and the selfdetermination of behavior. Psychological Inquiry: An International Journal for Advancement of Psychological Theory 2000;11:227-268. https://doi.org/10.1207/S15327965PLI1104_01

(8) Edwards A. Relational agency in professional practice: A CHAT analysis. Int J Hum Act 2007;1:1-17.

(9) Hökkä P, Vähäsantanen K, Paloniemi S, Eteläpelto A. Johtamisvalmennuksella toimijuutta esimiestyöhön: Työkaluja uudistamiseen, kohtaamiseen ja työidentiteettien tukemiseen. Kirjassa Vähäsantanen K, Paloniemi S, Hökkä P, Eteläpelto A. (toim.) Ammatillinen toimijuus: Rakenne, mittari ja tuki. Jyväskylä: Jyväskylän yliopistopaino; 2017:34-48.

(10) Pingree S, Hawkins R, Baker T, DuBenske L, Roberts LJ, Gustafson DH. The value of theory for enhancing and understanding e-health interventions. Am J of Prev Med 2010;38:103109. https:/doi.org/10.1016/j.amepre.2009.09.035

(11) Routasalo P, Airaksinen M, Mäntyranta T, Pitkälä K. Potilaan omahoidon tukeminen. Lääketieteellinen aikakauskirja Duodecim 2009;125:2351-9.
(12) Neuner-Jehle S, Schmid M, Grüninger U. The "Health Coaching" programme: a new patientcentred and visually supported approach for health behaviour change in primary care. BMC Fam Pract 2013;14:100. https://doi.org/10.1186/1471-2296-14-100

(13) Absetz P, Hankonen N. Elämäntapamuutoksen tukeminen terveydenhuollossa: vaikuttavuus ja keinot. Lääketieteellinen aikakauskirja Duodecim 2011;127:2265-72.

(14) Liddy C, Johnston S, Nash K, Ward N, Irving $\mathrm{H}$. Health coaching in primary care: a feasibility model for diabetes care. BMC Fam Pract 2014;15:60. https://doi.org/10.1186/1471-2296-15-60

(15) Kardakis T, Weinehall L, Jerdén L, Nyströn ME, Johansson H. Lifestyle interventions in primarly health care: professional and organizational challenges. Eur J Public Health 2014;1:79-84. https://doi.org/10.1093/eurpub/ckt052

(16) Allen C. Supporting effective lifestyle behaviour change interventions. Nurs Stand 2014;28:5158.

https://doi.org/10.7748/ns2014.02.28.24.51. e8049

(17) Michie S, Straalen MM, West R. The behaviour change wheel: A new method for characterising and designing behaviour change interventions. Implementation Sci 2011; 16:42. https://doi.org/10.1186/1748-5908-6-42

(18) Olander EK, Fletcher H., Williams S, Atkinson L, Turner A. French P. What are the most effective techniques in changing obese individuals' physical activity self-efficacy and behaviour: a systematic review and metaanalysis. Int J Behavl Nutr Phys Act2013;10:29. https://doi.org/10.1186/1479-5868-10-29

\section{Mari Punna \\ TtM lehtori \\ Jyväskylän ammattikorkeakoulu, Hyvinvointiyksikkö}

\section{Kaisa Malinen \\ PsT asiantuntija \\ Jyväskylän ammattikorkeakoulu, Hyvinvointiyksikkö}

\section{EIJA SEVÓN}

KT tutkijatohtori

Jyväskylän yliopisto, Kasvatustieteiden laitos

\section{SANna SiHvonen \\ TtT yliopettaja}

Jyväskylän ammattikorkeakoulu, Hyvinvointiyksikkö 